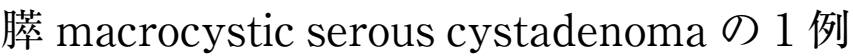

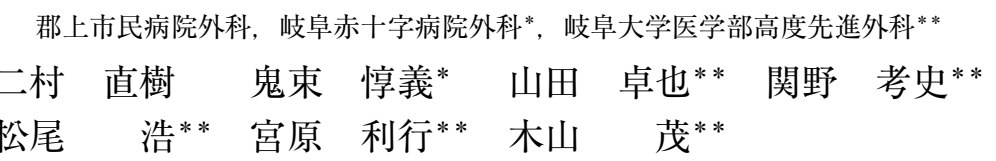

単房性囊胞の形態をした macrocystic serous cystadenoma（以下，MSCA）の 1 例を経験した ので報告する. 患者は 26 歳の女性で腹部腫瘤を主訴に受診し, 左季肋下に径約 $5 \mathrm{~cm}$ 大の腫瘤を 触知した. 膵炎や腹部外傷の既往はなく, 血液検査では異常を認めなかった. 腹部超音波検査, $\mathrm{CT}, \mathrm{MRI}$ では膵尾部に径約 $5 \mathrm{~cm}$ 大の単房性囊胞状腫瘤を認めた． ERP では主膵管と囊胞の交 通は認めなかった．腹部血管造影検査では脾動脈が頭側へ圧排されていた．膵粘液性囊胞腺腫 を疑って手術を行った．膵尾部に手拳大の囊胞状腫瘤を認め, 膵尾部切除を行った，摘出標本 では $60 \times 55 \times 45 \mathrm{~mm}$ 大の単房性囊胞を認め，内容は黄色透明な漿液であった，病理組織検査で は単房性の囊胞で, 囊胞壁には異型のない 1 層の立方上皮がみられた. 立方上皮は periodic acid-shiff 染色が陽性で，ジアスターゼによって消化された．以上の所見から，MSCA と診断し た.

\section{はじめに}

膵臓の漿液性囊胞腺腫（以下, SCA）の典型例 は小さな囊胞の集簇から成る蜂巣状腫瘤であり, 囊胞径は $2 \mathrm{~cm}$ までである ${ }^{1)}$. 比較的大きな囊胞が 目立つ非典型的な SCA は macrocystic serous cystadenoma $^{2)}$ (以下, MSCA) とされているが, まれである。

今回, 単房性囊胞の形態をした MSCA の 1 例を 経験したので報告する.

\section{症例}

患者 : 26 歳, 女性

主訴 : 腹部腫瘤

家族歴：特記すべきことなし.

既往歴：特記すべきことなし. 膵炎や腹部外傷 の既往はない.

現病歴：1997 年 6 月に腹部腫瘤に気づき, 近医 を受診した。腹部超音波検査, 腹部 CT で膵臓の 囊胞性腫瘤を疑われ，当院に紹介された.

入院時現症 : 左季肋下に径約 $5 \mathrm{~cm}$ で表面平滑,

$<2006$ 年 1 月 25 日受理 $>$ 別刷請求先 : 二村 直樹 厂501-4222 郡上市八幡町島谷1264 郡上市民病院外 科
弾性硬の腫瘤を触知した.

血液検査: 末梢血液検査, 生化学検査, 腫瘍マー カー（CEA，CA19-9）に異常を認めなかった.

腹部超音波検査：膵尾部に径約 $5 \mathrm{~cm}$, 球形の腫 瘤を認めた。内部は無エコーで後方エコーの増強 を認めた.内部に隔壁や隆起を認めなかった Fig. 1).

$\mathrm{CT}$ : 膵尾部に $5.0 \mathrm{~cm}$ 大の内部均一な腫瘤を認 めた (Fig. 2). 造影 CT で囊胞壁は造影されなかっ た.

MRI：膵尾部に径約 $5 \mathrm{~cm}$ 大の内部均一な腫瘤 を認めた. T1 強調画像で low intensity, T2 強調画 像で high intensity であった (Fig. 3).

$\mathrm{ERP}$ : 主膵管は膵尾部で圧排による屈曲を認め た. 囊胞との交通は認められなかった。

腹部血管造影検査 : 腹腔動脈造影検査で脾動脈 が頭側へ圧排されていた。血管の増生, encasement などを認めなかった.

鑑別診断として膵粘液性囊胞腫瘍, 仮性囊胞, 真性囊胞などが考えられた．膵炎や外傷のない若 年女性に発生し, 膵管との交通を認めない膵尾部 単房性囊胞のため, 膵粘液性囊胞腺腫を疑って手 
Fig. 1 Abdominal ultrasonography showed a 5.0$\mathrm{cm}$, unilocular cystic mass in the tail of the pancreas.

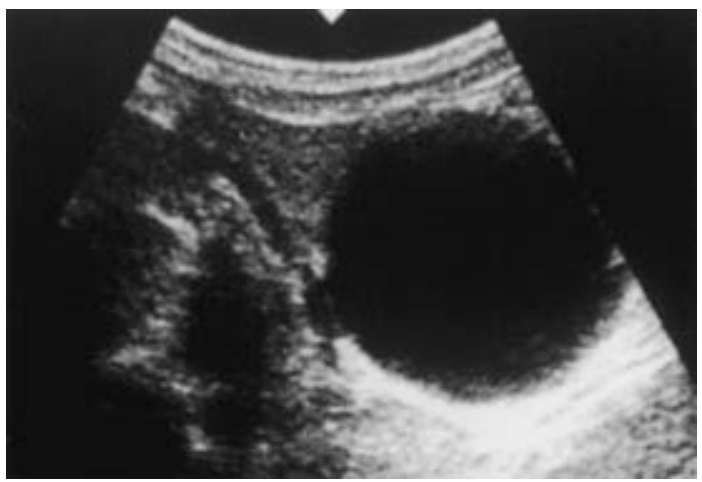

Fig. 2 Abdominal computed tomography showed a $5.0-\mathrm{cm}$, unilocular cystic mass in the tail of the pancreas.

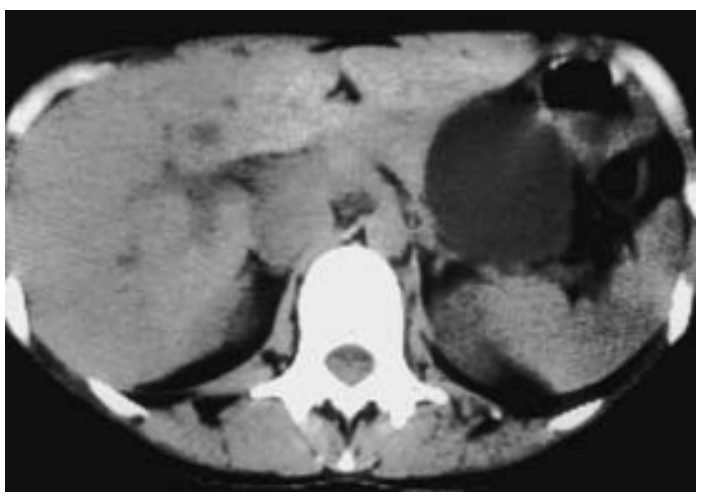

術を行った。

手術所見：囊胞部以外の膵臓は軟らかく, 周囲 との癒着も認めなかった。脾臓は温存して膵尾部 切除を行った。

摘出標本: $60 \times 55 \times 45 \mathrm{~mm}$ 大の囊胞を認め (Fig. 4A), 内容は肉眼的に黄色透明な漿液であっ た. 割面では壁の薄い単房性囊胞で囊胞内に隔壁 や隆起性病変を認めなかった (Fig. 4B)。囊胞液の 検査ではアミラーゼ $121 \mathrm{IU} / \mathrm{l}$, リパーゼ $31 \mathrm{U} / \mathrm{l}$, CEA0.1 以下 $\mathrm{ng} / \mathrm{ml}$, CA19-9 173U/ml であった.

病理組織学的検査所見: 単房性の囊胞で, 囊胞 壁には異型のない 1 層の立方上皮がみられた。囊 胞周囲にのみ線維化がみられたが，その他の膵臓
Fig. 3 Abdominal magnetic resonance imaging. A : T1-weighted image showed a low-intensity, unilocular cystic mass in the tail of the pancreas. B: T2weighted image showed a high-intensity, unilocular cystic mass.
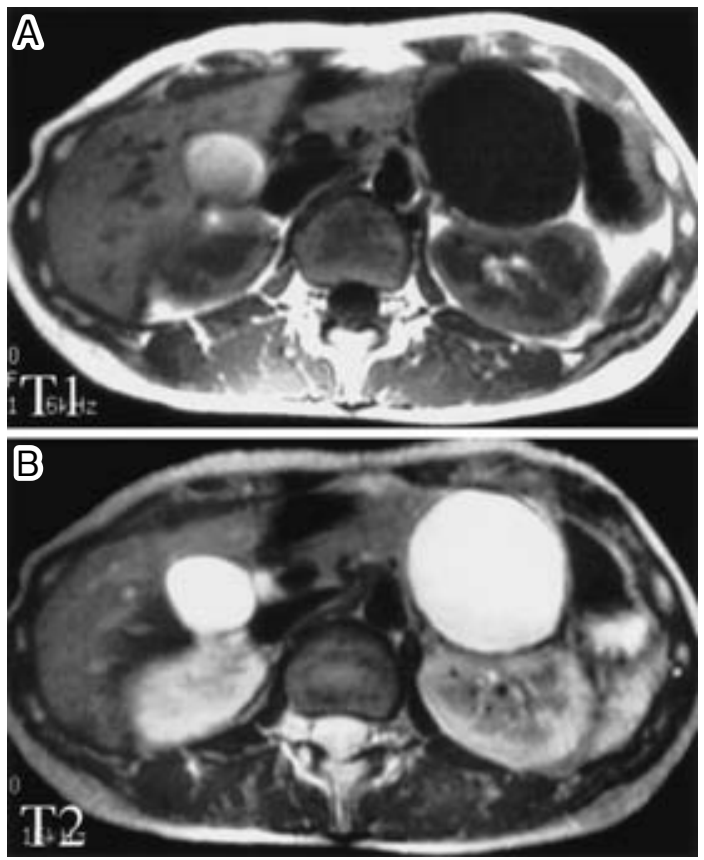

には炎症所見はみられなかった。立方上皮は periodic acid-shiff (以下, PAS) 染色が陽性でジアス ターゼによって消化された（Fig. 5)。これらの所 見から macrocystic serous cystadenoma と診断 した.

術後経過は良好で, 術後第 15 病日に退院した. 考察

1992 年に Lewandrowski ら ${ }^{2)}$ は, SCA において 径 $2 \mathrm{~cm}$ 以上の囊胞を macrocyst と考え, macrocystが主体の非典型的な SCA を MSCA として 報告した.

$\lceil$ macrocystic」をキーワードとして医学中央雑 誌，PudMed を用いて 1992 年〜2004 年までの検 索を行った、そこで得られた MSCAの論文とそれ らの論文の文献から MSCA の本邦報告例を集計 した. 報告例には最も大きな囊胞の径が $2 \mathrm{~cm}$ 未満 の症例でも MSCA として報告されていたため, 今 回の集計では Lewandrowski ${ }^{2)}$ の報告に従っ 
Fig. 4 Resected specimen. A : The resected tumor was a $6.0 \times 5.5 \times 4.5 \mathrm{~cm}$ sized cystic mass. B : Cut section of the resected specimen revealed a unilocular cyst with a thin wall.
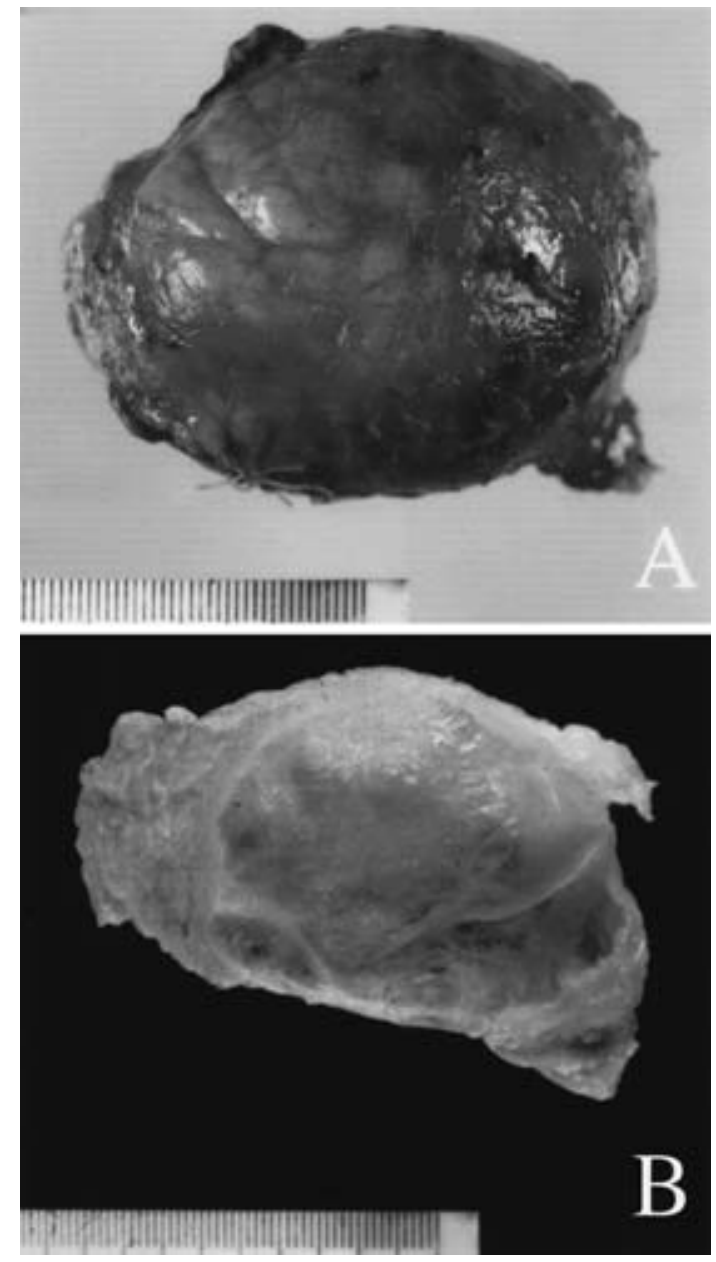

て, $2 \mathrm{~cm}$ 以上の大きな囊胞が主体の SCA を MSCA として集計した. MSCAの本邦報告例は 自験例を含めて 16 例であった ${ }^{3) ~ 17)}$. 性別は男性 6 例, 女性 10 例で, 年歯は 26〜 71 歳, 平均 55.1 歳であった，部位は頭部 5 例, 体部 8 例, 尾部 3 例であった. 病変部の大きさは $2.7 〜 7 \mathrm{~cm}$, 平均 4.7 $\mathrm{cm}$ であった，画像所見では単房性が 2 例, 多房性 が 12 例であり, 画像検査所見で単房性の 1 例は標 本の肉眼検査所見, 病理組織検査で多房性であっ た. 病理組織検査では単房性 1 例, 多房性 13 例で あり, ほとんどの症例で大きな囊胞の周囲に微小
Fig. 5 Microscopic examination of the specimen. A: The cyst was lined with a single layer of cuboidal epithelium $(\mathrm{HE}, \times 200)$. B : PAS staining was positive in the cytoplasm of the epithelium $(\times 200)$.
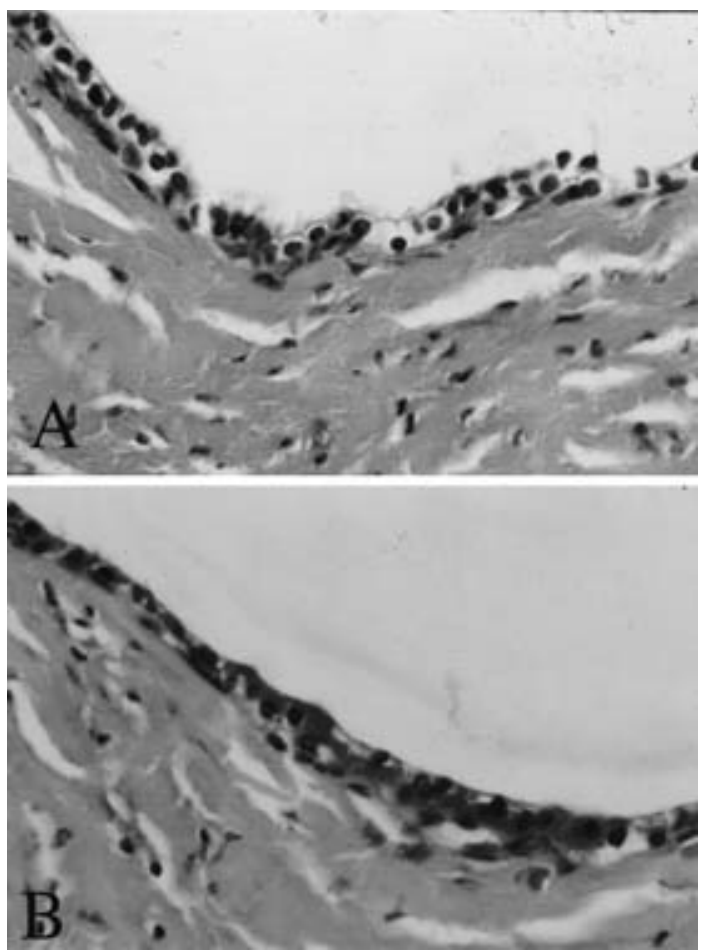

囊胞の集簇を認めた．単房性であったのは本例の みであった，病理組織検査では全例に囊胞壁に立 方上皮がみられ，11 例に細胞質に glycogen が豊 富であることが記載されている．戦房性や比較的 大きな囊胞の集簇であるため, 術前診断では粘液 性囊胞腫瘍が最も疑われており, 漿液性囊胞腺腫 と診断した症例は 4 例 58 8)1314)であった. 画像診断に は超音波内視鏡検査によって微小囊胞の集簇を検 出することが有用と報告されている ${ }^{1314}$. CohenScali ら ${ }^{18)}$ は単房性囊胞における MSCA と仮性囊 胞・粘液囊胞腺腫の CT 上の鑑別点について, 1) 膵頭部に存在すること，2）分葉状の形状，3）囊 胞壁が造影されないこと，4）囊胞壁が薄いこと (2mm 以下)の 4 点を挙げ，1），2），3）はMSCA に特異性の高い所見であった． 4 点中 2 点を認め る症例は MSCA の $83 \%$, 仮性囊胞・粘液囊胞腺 腫の $14 \%$ であり, 4 点中 3 点以上を認める症例は 
100\% で MSCA であったと報告している. 本例は 囊胞壁が造影されないこと, 囊胞壁が薄いことの 2 点を認めた.

本症例は若年女性で, 膵炎や外傷の既往がなく, 膵尾部に発生した単房性囊胞であり，膵管との交 通も認められなかった。これらの所見から術前に は膵粘液性囊胞腺腫を疑った。標本の肉眼検査所 見では単房性囊胞で, 内容は黄色透明な漿液で あった，病理組織検査では単房性囊胞で単層の立 方上皮がみられ，MSCA や solitary true cyst（以 下，STC）を疑った。腫瘍細胞の細胞質に豊富な グリコーゲンが証明されたため, MSCA と診断し た.

成人の STC は, 2001 年に Takahashi ${ }^{19}$ が自 験例 1 例と英語文献から合計 12 例を集計してい る. STC はまれな疾患と考えられるが, 膵臓の単 房性囊胞は経過観察されている可能性も考えられ る. STCは単房性の囊胞で, 病理組織検査では 囊胞壁に立方上皮がみられる，立方上皮は PAS 染色が陰性であり，この点でMSCA と鑑別され る. 成人の STC の報告例で PAS 染色が行われて いるのは 4 例と少なく ${ }^{19)}$, STC として報告された 症例に MSCA が含まれる可能性が示唆される.

Macrocystic SCA はまれな疾患であり，画像診 断で MCN が疑われる症例においても本疾患を念 頭におくことが重要である．画像診断や病理組織 検査で微小囊胞が確認されれば本疾患を強く疑う ことが可能である，単房性の場合，本疾患を疑う ことは困難であるが, 単房性膵囊胞の鑑別診断で も念頭におく必要があると考えられた。

\section{文献}

1) Compagno J, Oertel JE : Microcystic adenomas of the pancreas (glycogen-rich cystadenomas). A clinicopathologic study of 34 cases. Am J Clin Pathol 69 : 289-298, 1978

2) Lewandrowski K, Warshaw A, Compton C : Macrocystic serous cystadenoma of the pancreas. A morphologic variant differing from microcystic adenoma. Hum Pathol $23:$ 871-875, 1992

3) Mori $\mathrm{K}$, Takeyama $\mathrm{S}$, Hirosawa $\mathrm{H}$ et al : A case of macrocystic serous cystadenoma of the pancreas. Int J Pancreatol 17 : 91—93, 1995

4）山名大吾, 南部一郎, 大竹正一郎ほか：Macrocys- tic type の膵漿液性囊胞腺腫の 1 例. 臨放線 $40: 625-627,1995$

5）伊藤史人，世古口努，松本英一ほか：Macrocystic な形態を示した膵漿液性囊胞腺腫の 1 例. 胆と 膵 $17: 403$-408, 1996

6）松能久雄, 佐々木恵子, 小西二三男ほか：膵漿液 性囊胞腺腫の大細胞亜型の 1 例. 病理と臨 14 : 523-527, 1996

7) Kamisawa T, Egawa N, Ishiwata J et al : Macrocystic serous cystadenoma of the pancreas. Dig Endosc 9 : 296-299, 1997

8）伴 雅彦, 堀口祐爾, 今井英夫ほか: 非典型的な 画像所見を呈した膵漿液性囊胞腺腫の 1 例. 膵臓 $12: 39-45,1997$

9）高畑俊一, 井上重隆, 山口幸二ほか：macrocystic な形態を呈した膵 serous cystadenoma. 胆と膵 18 : 1082-1083, 1997

10) Inoue S, Yamaguchi K, Shimizu S et al : Serous cystadenoma of the pancreas with atypical imaging features : a new variant of serous cystadenoma of the pancreas. Pancreas $16: 102-106$, 1998

11）蒲地紀之, 村中 光, 安森弘太郎ほか：非典型的 な MRI 所見を呈した Macrocystic type の膵漿液 性囊胞腺腫の 1 例. 胆と膵 $20: 711-715,1999$

12) Fujiwara H, Ajiki T, Fukuoka K et al : Macrocystic serous cystadenoma of the pancreas. J Hepatobiliary Pancreat Surg 7 : 92-96, 2000

13) Kaneto H, Endo T, Ozeki I et al : Macrocystic serous cystadenoma of the pancreas : importance of co-existent tiny cysts depicted by EUS. J Gastroenterol $35: 472-475,2000$

14）若林時夫, 高橋志郎, 川浦幸光ほか：Macrocystic な形態を呈した漿液性膵囊胞腺腫の 1 例. 消画 像 2:5-7,2000

15）中村雄太, 乾 和郎, 芳野純治ほか: 漿液性囊胞 腺腫 (Macrocystic type) の 1 例. 胆と膵 21 : $766-767,2000$

16) Kobayashi $T$, Kawabe A, Uenoyama S et al : Macrocystic serous cystadenoma of the pancreas : case report. Abdom Imaging $26: 69-71,2001$

17) Hashimoto M, Watanabe G, Miura $Y$ et al : Macrocystic type of serous cystadenoma with a communication between the cyst and pancreatic duct. J Gastroenterol Hepatol 16 : 836-838, 2001

18) Cohen-Scali F, Vilgrain V, Blancatelli C et al : Discrimination of unilocular macrocystic serous cystadenoma from pancreatic pseudocyst and mucinous cystadenoma with CT : initial observations. Radiology $228:$ 727-733, 2003

19) Takahashi O, Kondo S, Hirano $S$ et al : Solitary true cyst of the pancreas in an adult. Int J Gastrointest Cancer $30: 165-170,2001$ 


\title{
A Case of Macrocystic Serous Cystadenoma of the Pancreas
}

\author{
Naoki Futamura, Atsuyoshi Onitsuka*, Takuya Yamada**, Takashi Sekino**, \\ Hiroshi Matsuo $^{* *}$, Toshiyuki Miyahara** and Shigeru Kiyama** \\ Department of Surgery, Gujo City Hospital \\ Department of Surgery, Gifu Red Cross Hospital* \\ Department of Advanced Surgery, Gifu University School of Medicine**
}

We report a case of macrocystic serous cystadenoma (MSCA) presenting as a unilocular cyst. A 26 year-old woman with a fist-sized mass in the left hypochondrium had no past history of pancreatitis or abdominal trauma. Laboratory data showed no significant abnormalities. Abdominal US, CT, and MRI showed a 5.0-cm, unilocular cystic mass in the tail of the pancreas. Endoscopic retrograde pancreatography showed no communication between the main pancreatic duct and the cyst. Abdominal arteriography showed displacement of the splenic artery. Surgery conducted under a diagnosis of mucinous cystadenoma of the pancreas and showed a fist-sized cystic tumor in the tail of the pancreas, necessitating resection of the tail of the pancreas. The resected $6.0 \times 5.5 \times 4.5 \mathrm{~cm}$ sized unilocular cystic mass contained yellow serous fluid. On microscopic examination, the cyst was lined with a single layer of cuboidal epithelium. Periodic acid-Shiff staining, with and without diastase digestion, showed abundant glycogen within epithelial cells, yielding a definitive diagnosis of MSCA.

Key words : serous cystadenoma, macrocystic, pancreatic cyst

[Jpn J Gastroenterol Surg 39 : 1403-1407, 2006]

Reprint requests : Naoki Futamura Department of Surgery, Gujo City Hospital 1264 Shimatani, Hachiman-cho, Gujo, 501-4222 JAPAN

Accepted : January 25, 2006 